\author{
MAŁGORZATA DAWIDZIAK-KŁADOCZNA \\ ORCID: 0000-0003-3602-2722 \\ Uniwersytet Wrocławski
}

\title{
Elementy sacrum w stylu prawno-urzędowym (na przykładzie dokumentów sejmików ziemskich doby średniopolskiej)
}

Wychodząc z założenia, że teksty są źródłem informacji o sposobie ujmowania rzeczywistości pozajęzykowej i funkcjonującym w niej systemie aksjologiczno-normatywnym ${ }^{1}$ (Kłoskowska 1991; Anusiewicz 1995; Dąbrowska, Anusiewicz (red.) 2000), zamierzam opisać jedną z właściwości komunikacji urzędowej doby średniopolskiej. Otóż w dokumentach będących przejawem tej sfery komunikowania, których podstawową funkcją jest ,regulowanie norm prawnych, czyli zasad współżycia obywateli w państwie" (Siuciak 2005: 124-125), przenikają się dwa wymiary — sacrum i profanum ${ }^{2}$. Oznacza to, że w stylu prawno-urzędowym (Wojtak 1993: 148) okresu od XVI do pierwszej połowy XVIII wieku dostrzegalne są elementy stylu religijnego, związane zwłaszcza ze sposobem obrazowania i prezentowania określonej wizji świata.

Podstawę materiałową niniejszego artykułu stanowią dokumenty sejmikowe. Mieszczą się one w trzech tomach Akt grodzkich i ziemskich z czasów Rzeczypospolitej Polskiej ${ }^{3}$, zawierających zróżnicowane pod względem gatunkowym pisma dotyczące działalności sejmiku ziemskiego obradującego w Wiśni w latach 1572-1732. Oczywiście nie w każdym tekście składającym się na ten obszerny

${ }^{1}$ Informacje o wartościach dominujących w poszczególnych okresach funkcjonowania społeczeństwa oraz o zmieniających się sposobach postrzegania przez nie rzeczywistości dostępne są dziś głównie dzięki tekstom, które są najlepszym źródłem wiedzy na temat wzorców kultury obowiązujących w danej społeczności.

2 Więcej na temat tej znanej w kulturze opozycji zob. w: Eliade 2008.

3 Akta grodzkie i ziemskie z czasów Rzeczypospolitej Polskiej, opr. A. Prochaska, t. XX. Lauda wiszeńskie 1572-1648, Lwów 1909; t. XXI. Lauda wiszeńskie 1648-1673, Lwów 1911; t. XXII. Lauda wiszeńskie 1673-1732, Lwów 1914. 
trzytomowy zbiór można odnaleźć elementy sacrum. Z drugiej strony zdarzają się dokumenty, w których motyw Boga pojawia się nawet kilka razy. Wśród nich przeważają lauda (czyli uchwały) sejmikowe oraz instrukcje sejmikowe (czyli wykaz zobowiązań przygotowany dla tych przedstawicieli sejmiku ziemskiego, którzy udawali się na sejm walny lub elekcyjny). Sfera sakralna uobecnia się też w innych tekstach reprezentujących takie gatunki wypowiedzi, jak m.in.: odpowiedź królewska, uniwersał, ordynacja lub konfederacja.

Z dzisiejszej perspektywy badane akta są niejednorodne stylistycznie, ponieważ na styl urzędowy ${ }^{4}$ nakłada się styl religijny ${ }^{5}$. Patrząc jednak na problem z perspektywy dawnej, należy stwierdzić, że obecność wyznaczników przynależnych sacrum jest jedną z cech ówczesnego komunikowania. Jest ono bowiem nierozłącznie związane z kulturą, w której się odbywa. Sfera duchowa w dobie średniopolskiej, zwłaszcza w XVII wieku, czyli w okresie baroku, była „uwikłana [...] w różne aspekty ówczesnego życia społecznego" (Adamiec 2007: 25). Można więc mówić o szerszej tendencji, wręcz o procesie „sakralizacji [...] kultury” (Tazbir 1974: 249), co w dużej mierze było rezultatem zarówno reformacji, jak i kontrreformacji. W tym czasie dominowała też ideologia sarmatyzmu, utożsamiająca Polaka-patriotę z katolikiem. O oddziaływaniu katolicyzmu i reformacji na piśmiennictwo, literaturę i odmianę retoryczną komunikacji językowej pisano już wielokrotnie, podkreślając na przykład, że ,język służy wyrażaniu treści kulturowych, ale sam ulega wpływom płynącym z różnych sfer kultury, także ze sfery życia religijnego" (Bajerowa 1993: 7). Ponadto należy pamiętać, że styl urzędowy w początkowej fazie rozwoju „wpisuje się w łacińsko-chrześcijański wzorzec kulturowy" (Siuciak 2011: 287).

W dalszej części artykułu omówię różne przejawy sacrum w dokumentach sejmikowych. Na początku opiszę odwołania do Boga sytuujące się na poziomie pragmatycznym, a konkretnie odnoszące się do miejsca obrad i sposobów określania czasu ich odbywania. Następnie zaprezentuję typowe akty mowy, w których wyraźne są nawiązania do wiary katolickiej, a nawet szerzej — chrześcijańskiej. W tym miejscu analizy pragmatycznojęzykowe zostaną uzupełnione o uwagi stylistycznojęzykowe, ponieważ opisywane intencje komunikacyjne są realizowane za pomocą specyficznej leksyki. Wszystkie te zabiegi z jednej strony prowadzą do wykreowania pewnego obrazu Boga, z drugiej zaś są świadectwem sposobu pojmowania go przez ówczesne społeczeństwo. Właśnie dlatego zamierzam przedstawić obecność pierwiastków sakralnych również w sferze poznawczej ${ }^{6}$.

${ }^{4} \mathrm{~W}$ stylu urzędowym dominują następujące funkcje: informacyjna, impresywna oraz sprawcza. Badane teksty reprezentują kancelaryjną odmianę stylu urzędowego, którą cechuje szablonowość, powtarzalność spetryfikowanych formuł a także dążność do precyzji.

${ }^{5}$ Widać tu także wyraźne oddziaływanie stylu retorycznego. Por. Dawidziak-Kładoczna 2018.

6 Warto dodać, że religia przejawia się także w tematyce analizowanych pism, ponieważ wiele norm prawnych dotyczy spraw (np. administracyjnych, gospodarczych czy finansowych) Kościoła lub klasztorów. Tego typu odwołań nie omawiam jednak w tym artykule. 


\section{Sakralizacja przestrzeni obrad sejmików ziemskich}

Zacznę od omówienia tego przejawu sacrum, który jest związany z uwarunkowaniami komunikacyjnymi wypowiedzi, a mianowicie z miejscem obrad. Odbywały się one na ogół w świątyniach ${ }^{7}$ i rozpoczynały mszą świętą, mimo że wśród uczestników byli również niekatolicy. Już sam ten fakt świadczy o zależności sejmików ziemskich od religii oraz o prymacie wyznania katolickiego nad innowierczymi (Kalwat, online). Informacje o lokalizacji sejmików zwerbalizowane są również w dokumentach, które powstawały w trakcie obrad, przede wszystkim w laudach: „zasiedliśmy na zwyczajnym miejscu w kościele” (XX 141) ${ }^{8}$, „My rady, dygnitarze, urzędnicy, rycerstwo ziemie przemyskiej województwa ruskiego [...] do kościoła katedralnego przemyskiego zjechawszy się i zgromadziwszy tośmy postanowili” (XXI 128), „Działo się w Wisni w kościele farnym” (XXI 367). Szlachta nie zawsze jednak potrafiła uszanować te święte miejsca i profanowała je. Jak podkreślają historycy, dyskusje sejmikowe często były „,burzliwe i gorszące”, obradujący kłócili się, obrzucali wyzwiskami i dopuszczali rękoczynów, „świątynie nieraz oblegano zbrojnie”, a czasem dochodziło nawet do krwawych walk (Widacka, online) ${ }^{9}$.

\section{Czas święty jako element determinujący obrady sejmików ziemskich}

Przyjmując pogląd, zgodnie z którym „każda kultura ma swój określony profil temporalny, sposób doświadczania i odnoszenia się do czasu" (Warczok 2010: 120), warto ustalić, jak ta kategoria jest realizowana w badanych tekstach. Otóż w aktach sejmikowych czas świecki ${ }^{10}$ (społeczny, kulturowy, historyczny, agrarny $^{11}$ ) splata się z czasem świętym ${ }^{12}$, którego miarę stanowi rok liturgiczny ${ }^{13}$

7 W trakcie obrad wynoszono z kościoła Przenajświętszy Sakrament (Widacka, online).

8 Po cytacie w nawiasie podaję lokalizację cytatu: tom akt sejmowych (liczbą rzymską) oraz numer strony (liczbą arabską).

9 Takie zachowanie opisują również poeci, np. Wacław Potocki: „Maluj, diable, sejmiki, gdzie siadłszy w kościele, / Sami nie wiedząc, przy czym, drze szlachta gardziele” (Widacka, online).

${ }^{10}$ Czas świecki jest nieodwracalny, czas święty — odnawialny, okrężny, cykliczny (Eliade 1970).

11 O zależności sfery gospodarczej i wyznaniowej tak pisze Dorota Adamiec: „Obowiązki religijne w dobrze ustalonym rytmie roku liturgicznego splatały się [...] z rodzimą obrzędowością starego kalendarza rolniczego" (Adamiec 2007: 31).

12 Jak pisze Eliade, ,jest to czas stworzony i uświęcony przez bogów” (Eliade 2008: 70).

13 O świeckim użyciu określeń czasu, które genetycznie były związane z kultem religijnym, pisze Dorota Adamiec (2007). Badaczka wspomina jednak tylko o takich połączeniach wyrazowych, jak wielki post, post czterdziestodniowy, dni krzyżowe, niedziela zapustna, kwietna niedziela, które nie pojawiają się w badanym przeze mnie materiale. 
i w którym centralne miejsce przypada uroczystościom i świętom. Przejawem tego może być zwyczaj zwoływania sejmiku w dniu, który pozostaje w jakichś relacjach do święta katolickiego. Najczęściej był to pierwszy poniedziałek po Narodzeniu Najświętszej Marii Panny (czyli po 8 września), chociaż zdarzało się odbywanie sejmików w innym terminie — na ogół także następującym po czasie sakralnym ${ }^{14}$.

Naturalną konsekwencją opisanego zwyczaju jest używanie w aktach sejmikowych określeń temporalnych nawiązujących do sacrum. Taka tendencja ma miejsce do lat 80 . XVII wieku. Jej tekstowe potwierdzenia znajdują się zatem w tomach XX, XXI i na początku XXII analizowanych dokumentów. Określenia temporalne wyrażane są w języku polskim: „Działo się w Wiśni na sejmiku we środę w dzień Świętego Krzyża” (XX 38), „działo się w poniedziałek w dzień podniesienia św. Krzyża roku pańskiego [...]" (XX 131) lub rzadziej — łacińskim: „Działo się w Wisni na sejmiku electionis deputati feria secunda post festum Nativitatis Beatissimae Virginis Mariae proxima anno Domini millesimo sexcentesimo septuagasimo quinto" (XXII 34). Datowanie sejmiku oparte na odwołaniu się do wydarzeń religijnych skutkuje czasami przeniesieniem określenia temporalnego na nazwę sejmiku: „najdalej we dwie niedziele po sejmiku Świętego Krzyża" (XX 37).

Nawiązujące do sfery sakralnej określenia temporalne stosowane są również, gdy mowa o innych wydarzeniach przeszłych lub dopiero mających nastąpić: $n a$ niedziele przewodnia, we wtorek po świętej Agnieszce, po środopostnej niedzieli, w poniedziałek po św. Barbarze, poniedziałek przed św. Tomasza apostoła. Zjawisko to egzemplifikują następujące fragmenty: ,abyśmy ze Lwowa nie odjeżdżali od dnia dzisiejszego tj. poniedziałku przed św. Tomasza apostoła do dwu niedziel, czekając, czego Panie Boże uchowaj, wtargnięcia wedle możności swej od tego nieprzyjaciela” (XX 42), „Sądy skarbowe we Lwowie w poniedziałek po św. Janie do sądu ziemskiego grodzkiego lwowskiego naznaczamy" (XXI 377).

\section{Sakralizacja leksyki}

Z cytowanych wcześniej fragmentów wynika, że w dokumentach sejmikowych sakralizacji podlega sfera leksykalna, czego sygnałem są takie wyrazy, jak rzeczowniki święto i świątnica, a także przymiotniki święty ${ }^{15}$ (określający słowa Krzyż, pokój, ołtarz, Trójca, sprawiedliwość, wiara, męka), najświętszy (to określenie pojawia się tylko w nazwie święta Najświętszej/Naświętszej Maryi Panny)

14 Chodzi tu np. o Wniebowzięcie NMP (15 sierpnia) lub Podwyższenie Krzyża Świętego (14 września).

15 Święty w znaczeniu sanctus używany jest w języku polskim właśnie od XVI wieku (Boryś 2005: 623). 
i świątobliwe (zwyczaje) oraz przysłówek świętobliwie (na ogół jako określenie czasownika przyrzekać). W badanych tekstach liczne są również neutralne nazwy osobowego sacrum, czyli Pan Bóg, Bóg, Pan, Deo (nazwa ta wskazuje też na inną cechę dawnych pism sejmikowych — poddawanie się wpływom łaciny) oraz nazwy wartościujące: Opatrznośc $c^{16}$, w tym nominacje peryfrastyczne, np. providentia/ prowidencya Boska, Pan zastępów. Oto fragmenty potwierdzające powyższe stwierdzenia: ,dziękujemy [...] najwyższemu Panu [...], że [...] pozwala nam providentia Boska dalsze około tej Ojczyzny [...] obrady" (XXII 233), „Wielkie to jednak opatrzności Boskiej uznawamy dzieło, że jako nas w całości dotąd zatrzymywa tak i radzić o sobie pozwala" (XXI 149). Spośród innych osób związanych z sacrum wymieniana jest Matka Boska, ale na ogół jej imię jest wyrażane po łacinie Matris Deo ${ }^{17}$ : „J. kr. Mć p. n. m. z IMciami pp. senatorami na ten czas przy boku swym będącymi solleni obligował nas wszystkich w osobie swojej pańskiej przed ołtarzem Bożym et Matris Dei voto" (XXI 270). Ponadto stosowane są inne wyrazy należące do pola semantycznego religii, np. dom Boży, niebo, krzyż, przy czym najczęściej używane są w kontekstach wyraźnie wartościujących. Przykładem może być zastosowanie metafory matki w odniesieniu do nazwy instytucji - Kościoła: „Kościół matka tylko na nieznośnie wykraczających synów pozwoliła” (XXII 524).

\section{Związek motywów sakralnych z wybranymi aktami mowy}

Największą grupą leksyki nawiązującej do sfery wyznaniowej jest frazeologia, której użycie wiąże się z konkretnymi aktami mowy. Na ogół pełnią one funkcję etykietalną. Nawiązania do Boga towarzyszą bowiem tytulaturze, podziękowaniom i życzeniom.

Odwołanie się do sfery nadprzyrodzonej jest cechą standardowej formuly $z$ Bożej taski król Polski, która występowała w wielu aktach prawnych nie tylko doby średniopolskiej (zwanych wówczas konstytucjami), lecz także nowopolskiej ${ }^{18}$. W badanym materiale właśnie $\mathrm{w}$ taki sposób w segmencie inicjalnym tytułuje się nadawcę (czyli króla), kierującego dokumenty do kasztelana, senatorów lub innych dostojników, np. „Jan Kazimierz z Bożej łaski król polski, wiel-

${ }^{16}$ Używanie wyrażenia opatrzność Boska jest wyrazem siedemnastowiecznej idei wiary w pomoc Boga, jego interwencję i ingerencję w sytuacji zagrożenia (Matuszczyk 2001). W tym wypadku zawsze chodzi o zagrożenie narodu.

17 Wariant Matris Deo występuje zamiast formy Beatae Mariae Virginis. Jak zaznacza Cybulski, „[Matka Boska - M. D.-K.] w zasadzie nie weszła do staropolskiego obyczaju językowego” (Cybulski 1992: 202).

18 W ustawie rządowej z dnia 3 maja 1791 roku pojawia się następujące połączenie językowe: „Stanisław August z Bożej łaski i woli narodu król polski”. 
kie książę litewskie, ruskie [...], czerniechowskie a szwedzki, godzki, wandalski dziedziczny król. Urodzony wiernie nam miły!” (XXI 227). Pierwiastek sakralny pojawia się też w tytule przewielebni w Bogu, który stosuje się w odniesieniu do zbiorowości, jaką są dygnitarze, urzędnicy i obywatele stanu szlacheckiego: „Wszem w obec i każdemu z osobna komu o tem wiedzieć należy a mianowicie przewielebnym w Bogu, Wnym, urodzonym dygnitarzom, urzędnikom i wszytkim obywatelom stanu rycerskiego ziemie lwowskiej uprzejmie i wiernie nam miłym łaskę naszą królewską" (XXI 366).

Jeśli chodzi o dziękczynienie, to jest ono skierowane do istoty najwyższej i połączone z wyrażeniem jej uwielbienia. Głównym ośrodkiem takich związków wyrazowych są wyrazy: dzięki, chwała i pochwalony: Panu zastępów pokorne dzięki, Panu Bogu dzięki oddajemy, chwała Bogu, chwała Boża, Pan Bóg niech będzie za to pochwalony. Oto przykład użycia jednego z tych połączeń wyrazowych w badanym materiale: ,[...] podźwignioną tęż ojczyznę przez łaskę wprzód Bożą a potem usiłowania pracę odwagę J. kr. Mci p. n. m. widzimy, jako powinne Panu Bogu dzięki oddajemy" (XXI 240).

Akty etykiety językowej wypełniają również życzenia, ponieważ ,przywołanie majestatu boskiego wzmacnia pozytywną siłę życzeń i podkreśla pragnienie wypowiadającego, aby się spełniły" (Adamiec 2007: 102). Odbiorcą tego typu grzecznościowych aktów mowy jest najczęściej władca, a pojawiają się one na początku dokumentu. Ustawodawca życzy królowi przede wszystkim zdrowia oraz siły pochodzącej od Boga. Oto najczęściej używane formuły w tej funkcji: życząc, aby Pan Bóg [...], życzymy dobrego od Pana Boga zdrowia, aby najwyższy Pan positkowat intencje, np. ,[...] życząc tego wiernie, aby Pan Bóg J. kr. Mć w dobrem zdrowiu z sławnem zwycięstwem do nas przeprowadzić raczył" (XX 130).

W pewnym sensie aktem mowy podobnym do życzeń są prośby, co wynika zarówno z ich etykietalnej obudowy, jak i z intencji nadawcy, a konkretnie z jego pragnienia, by spełniło się to, co uważa za dobre, korzystne. Prośby związane są jednak również $\mathrm{z}$ oddziaływaniem na odbiorcę - w tym wypadku na istotę najwyższą, a więc cechuje je również impresywna moc illokucyjna. Zostaje ona wzmocniona właśnie dzięki przywołaniu pierwiastka sakralnego. Tendencję tę w następujący sposób thumaczy Dorota Adamiec:

Niezachwiana wiara we wszechmogącą ingerencję boską w ziemskie sprawy stanowi mocny fundament, na którym ówcześni ludzie budują swoje stosunki z Bogiem. W centrum relacji człowieka do Boga znajduje się postawa prosząca. Ludzie nieustannie proszą Boga, przede wszystkim o opiekę i obronę przed otaczającym ziemskim złem (Adamiec 2007: 73).

Głównym ośrodkiem zwrotów wyrażających prośbę w aktach sejmiku wiszeńskiego są czasowniki strzec, prosić, uchować, dać. Najobszerniejszy zbiór w tej grupie stanowią zwroty daj Boże, strzeż Boże i uchowaj Boże, które w badanym materiale pojawiły się kilkaset razy. Można nawet mówić o automatyzacji 
tego typu wykładników modalności ekspresywnej (por. Cybulski 1992: 194), której towarzyszy wariantywność, np. da Bóg, daj Boże, co Panie Boże daj.

Szczególną formą nawiązań do religii są zwroty, które pierwotnie pełniły funkcję prośby o miłosierdzie. W aktach sejmikowych używa się ich jednak w znaczeniu i funkcji wtórnej. Wiążą się one przede wszystkim z werbalizowaniem emocji, a więc $\mathrm{z}$ intencją ekspresywną. Mowa tu o zwrotach żal się Boże, pożal się Boże, np. ,a już pożal się Boże i sami synowie koronni ex praecipuis ich radami i assistencyami infascinati zostają" (XXI 423).

Frazeologia religijna może być też wykorzystywana w aktach mowy pełniących funkcję performatywną, np. w przysięgach przytaczanych w aktach sejmikowych. Służy wówczas wzmocnieniu i potwierdzeniu prawdziwości przyrzeczenia. W tego typu wypowiedziach Boga uznaje się za gwaranta prawdy, a ,przywołanie majestatu boskiego odgrywa rolę definitywnego uwiarygodnienia wypowiedzi” (Adamiec 2007: 95). Autorytet religijny potwierdza zatem wiarygodność nadawcy (Adamiec 2007: 97). Odwołanie do majestatu Boga ma też na celu wyrażenie prośby o wsparcie w dążeniu do realizacji postanowienia (Adamiec 2007: 98). Tak oto motywy sakralizacji tekstu przysięgi wyjaśnia Marek Cybulski: „Sankcję religijną nadawano powszechnie wypowiedziom performatywnym, stąd też utrwaliły się pewne religijne frazeologizmy jako elementy towarzyszące performatywom" (Cybulski 1992: 200).

Omawiane formuły w badanych przeze mnie dokumentach stanowią dość liczny zbiór: brać na świadectwo Pana Boga, przed Panem Bogiem oświadczyć się, oświadczenie przed Bogiem, oświadczyć się raczy J. kr. Mć przed Panem Bogiem, manifestować się przed Bogiem, przed Panem Bogiem światobliwie przyrzekamy, przysięgać Panu Bogu. Oto przykłady ich realizacji: ,[...] tak na niewinne przed Bogiem i światem oraz całym manifestując się objekcye, solicitis praecibus upraszamy W. ks, Mci, abyś [...]” (XXII 550), „Ja N. przysięgam P. Bogu wszechmogącemu w Trójcy świętej jedynemu, iż przy wierze świętej katolickiej [...] obowiązuję się i powinienem będę. [...] Tak mi Panie Boże dopomóż i męka jego święta" (XXII 389). Schemat przysięgi zastosowany w ostatnim przykładzie jest bardzo częsty, może on występować w różnych wariantach, również w wersjach bardziej ekonomicznych, np. „Ja Mateusz przysięgam Panu Bogu Wszechmogącemu etc., iż [...], ale według Boga prawa napisanego [...]. Tak mi P. Boże dopomóż etc." (XXII 592). Większość z przysiąg kończy formuła tak mi Panie Boże dopomóż, której ośrodkiem również jest komponent sakralny.

Podsumowując tę część analiz, trzeba stwierdzić, że leksyka i frazeologia religijna - w zależności od aktu mowy, w którym zostały użyte — pełnią funkcje etykietalną, impresywną, ekspresywną lub performatywną. Ponadto zawsze są elementem pewnego ceremoniału, stanowią zatem przejaw rytuału językowego. Poza tym są nośnikiem określonej wizji świata. Temu zagadnieniu poświęcę ostatnią część analizy. 


\section{Wpływ sacrum na prezentowaną wizję świata}

Sakralizacja związana jest również ze sferą wartości, które są utrwalane w tekstach i przez nie przekazywane. Chodzi tu o obraz Boga zawarty w badanych dokumentach. Ich lektura uzmysławia, jakie było znaczenie wyznania dla ustawodawcy reprezentowanego przez przedstawicieli stanu szlacheckiego.

Bóg, którego przywołuje się w aktach sejmikowych, to Bóg CHRZEŚCIJAN. Wiara $\mathrm{w}$ niego nakazuje walkę z innowiercami, którzy metonimicznie nazywani są nieprzyjaciótmi krzyża świętego, nieprzyjaciótmi Bożymi i katolickimi, np. „nieprzyjaciel krzyża świętego non sine gravi christianitatis dolore” (XXII 1), „przez co różne scandala et inconvenientia narodowi chrześcijańskiemu od tych nieprzyjaciół Bożych i katolickich ingeruntur" (XXII 132). Czynnik religijny wykorzystywany jest zatem jako argument uzasadniający toczenie wojen z Turkami czy Tatarami. Przywołanie Boga stanowi niejako usprawiedliwienie działań podejmowanych w stosunku do innowierców. Te wnioski, będące rezultatem analiz konkretnego materiału, potwierdzają ogólniejsze spostrzeżenie, zgodnie z którym właśnie $\mathrm{w}$ dobie średniopolskiej rodzi się sarmacki mesjanizm. Zafascynowana tą ideą szlachta upatrywała misji Rzeczpospolitej w obronie wiary przed innowiercami (Adamiec 2007: 30). Badane teksty dowodzą, że chrześcijaństwo jest głęboko zakorzenione w społeczeństwie, co dokumentuje często eksponowane przeświadczenie o obowiązku wierności mu: „Jako zaś prześwietne województwo ruskie nie tylko rzptej, ale całego chrześcijaństwa zawsze było" (XXII 472). Manifestowane jest również przywiązanie do katolicyzmu: „przy wierze świętej katolickiej, świątnicach Bożych, dostojeństwie J. kr. Mci, przy prawach i swobodach ojczystych, odżałowawszy reszty fortun i zdrowia naszego sprzysięgliśmy się" (XXII 632).

W wielu dokumentach sejmikowych Bóg jawi się jako STWÓRCA, co potwierdza wyrażenie dzieło boskie, a także DAWCA i SPRAWCA pokoju, bezpieczeństwa i sprawiedliwości. To od jego woli uzależnia się zwołanie i odbycie sejmiku oraz stawienie się na sejmik szlachty i uchwalenia prawa. $Z$ takich połączeń językowych, jak da Bóg, daj Boże, co Panie Boże daj, dar Boży, łaska Boża wynika, że istota nadprzyrodzona wpływa na losy ojczyzny oraz na życie człowieka. Bóg jest również PRAWODAWCĄ, czyli tym, który stoi ponad świeckimi stanowiącymi prawo. To oni, tworząc normy, muszą zważać na prawo Boże: ,przy niem stawać i w niczem go naruszać, jako z prawem Bożem et cum omnium regnorum iure zgadzającym się nie pozwolimy” (XXII 62).

Ponadto Bogu należy się wdzięczność za łaski, którymi obdarza. Jest zatem również BIORCĄ ofiar składanych przez człowieka, co zaświadczają wyrażenia: oddać Panu Bogu rationem, powinne Panu Bogu dzięki oddajemy, powinniśmy wdzięczność oddać majestatowi Boskiemu, wdzięczna Bogu ofiara, wdzięczność dobroci Boskiej. 
Z laudów, instrukcji i uniwersałów wynika, że BÓG jest również OPIEKUNEM oraz OBROŃCA państwa, narodu i pojedynczego człowieka, co jest werbalizowane za pomocą takich wyrazów i związków wyrazowych, jak Opatrzność, Opatrzność Boża oraz prowidencya Boska. Człowiek zawsze może liczyć na Boga WSPOMOŻYCIELA, który jawi się jako źródło pomocy. Dowodzą tego rzeczownik pomoc (i jego łaciński odpowiednik solacium) oraz czasowniki pomóc, dopomóc i pomagać, będące ośrodkiem takich frazeologizmów, jak: tak mi Panie Boże dopomóż, Pana Boga wziq̨wszy na pomoc, Boga zastępów wziąwsy na pomoc, Pan Bóg mittet solacium. Oto fragment dokumentu zawierającego jeden z wymienionych frazeologizmów: „ażali z przezorności W. ks. Mci mittet Pan Bóg solacium jakie" (XXII 580).

Ustawodawca prezentuje najwyższą istotę również jako STRAŻNIKA wartości ważnych dla szlachty. Taki wizerunek jest rezultatem zastosowania zautomatyzowanych, utartych połączeń wyrazowych, takich jak strzeż Boże, uchowaj Boże, czego Panie Boże uchowaj, np. „A jeśliby uchowaj Boże, ingruens jakie periculum od cesarza tureckiego na Rzpltą przypadać miało [...] tedy" (XX 441).

Bóg przedstawiany jest ponadto jako WŁADCA rządzący zastępami (Pan zastępów). Kształtując taki wizerunek Boga, szczególnie eksponuje się tu stosunek człowieka do niego (sługa Boży). Jego władza jest nieograniczona, ponieważ nie tylko rządzi, ale również sądzi. Jest zatem SĘDZIĄ, którego wyróżnia SPRAWIEDLIWOŚĆ: „Kiedy się kto paenitus wpatrzy in sortes regnorum, musi przyznać, że Bóg wszędzie jednaki na równiej szali złe i dobre narodom rozdziela i portione szczęśliwych albo przeciwnych influencyi dotat” (XXII 265). Temu pozytywnemu wizerunkowi przeciwstawiony jest obraz sędziego SUROWEGO, o czym świadczą takie związki wyrazowe, jak pomsta Boża, plagi Boże, pokarat Rzeczpospolita, ogniem dotkną, karczma pogorzała z dopuszczenia Bożego, zesłał plagi, np. ,za tak żałośnem rozjechaniem naszem i braciej naszej z Warszawy, jakiem nas Pan Bóg pokarał” (XX 71), „ten kraj [ziemia lwowska - M. D.-K.] plagami Bożemi [...] zniszczony" (XXII 504). Ambiwalentny obraz Boga znajduje potwierdzenie również w innych tekstach średniopolskich (por. m.in. Wincewicz 2015; Książek-Bryłowa 2001).

Jeśli chodzi o inne cechy Boga eksponowane w aktach sejmiku wiszeńskiego, to zwraca się uwagę na to, że jest on DOBRY (dobroć Boska), MIŁOSIERNY (Bóg zmiłuje się nad utrapiona ojczyzna), ŁASKAWY (laska Boża), WSZECHMOGĄCY (Bóg wszechmogący, Pan Bóg wszechmogacy) i NAJWYŻSZY (najwyższy Pan). Poza tym przynależą mu MAJESTAT (majestat Boski) i CHWAŁA (chwała Boża/Boska, chwała Bogu).

Podsumowując tę część analiz, warto dodać, że Bóg w średniopolskich aktach urzędowych ukazywany jest podobnie jak w literaturze tego okresu jako sędzia, władca i dawca (por. m.in. Książek-Bryłowa 2001; Obremski 1991; Rzepka, Walczak 1999; Strykowska 1999; Wincewicz 2015). Wniosek ten nie powinien zaskakiwać, zważywszy na to, że styl językowy oddaje porządek kultury, jest 
znakiem emocji, którymi kieruje się dana grupa społeczna, jest przejawem jej zwyczajów, a także odzwierciedla jej punkt widzenia. W dobie średniopolskiej przywoływanie Boga było traktowane jako sygnał tożsamości obywatela Rzeczypospolitej.

\section{Podsumowanie}

Chociaż styl urzędowy traktowany jest przez wielu badaczy jako wyjątkowo stabilny (Siuciak 2005), to za sprawą przemian kulturowych, politycznych i ustrojowych pewne jego cechy podlegają bardzo wyraźnym przekształceniom. Jedną z nich są elementy sacrum — nieobecne we współczesnej komunikacji urzędowej, a typowe dla tekstów prawnoustrojowych doby średniopolskiej. Okazuje się też, że zauważalne są pewne różnice w liczbie i charakterze odwołań religijnych w okresie badanych 150 lat. Na przykład popularne w XVI wieku i w pierwszej połowie XVII wieku wyrażenia temporalne zawierające pierwiastek sakralny w późniejszym okresie całkowicie ustępują miejsca określeniom nawiązującym do kalendarza świeckiego.

Wątki wyznaniowe pełnią funkcję rytualną i etykietalną. Pojawiają się często zaraz po inicjalnym segmencie, który tworzą określenia lokatywne i temporalne. Wszelkie odwołania się do Boga są wyrazem światopoglądu ówczesnych ludzi, znakiem ich wiary, a także obowiązującej wówczas konwencji. To właśnie obecność czynnika nadprzyrodzonego w świecie człowieka ułatwia porządkowanie ludzkich spraw i właściwe ich hierarchizowanie. Odwołując się do sacrum, ustawodawca wykorzystuje utarte schematy językowe. Tej formuliczności towarzyszy wariantywność. Obie cechy są typowe dla średniopolskiego stylu urzędowego.

Otwarte pozostaje pytanie, czy omawiane związki wyrazowe są dowodem na sakralizację stylu urzędowego, czy raczej na laicyzację zwrotów, które pierwotnie miały wartość religijną. Ten drugi proces określa się jako desakralizację frazeologizmów. Polega on na przemianach semantycznych od sacrum do profanum, a konkretnie na przenikaniu do języka ogólnego połączeń leksykalnych z komponentem konfesyjnym. Za drugim rozwiązaniem przemawia fakt używania elementów leksykalnych należących do etykiety językowej i wyrażających emocje. Wydaje się, że badane teksty dokumentują początkową fazę zeświecczania frazeologii religijnej ${ }^{19}$. Trudno również dziś ustalić, czy osoby, które używały leksyki religijnej, robiły to odruchowo, konwencjonalnie czy świadomie odwoływały się do pierwiastków świętych. Obie postawy nie muszą się jednak wykluczać, bo „desakralizacja nie powoduje eliminacji więzi tych jednostek języka ze sferą sacrum" (Adamiec 2007: 157). Dotyczy to zwłaszcza połączeń

19 Dzieje się tak na skutek regularnego używania frazeologizmów biblijnych w kontekstach niesakralnych (Adamiec 2007). 
wyrazowych, które wypełniają akty etykiety językowej oraz służą werbalizowaniu emocji, a te — inaczej niż dziś — są ważnymi elementami średniopolskiej komunikacji urzędowej.

\section{Bibliografia}

Adamiec D. (2007), Frazeologia religijna okresu baroku (na tle tendencji kulturowych epoki), Kraków.

Akta grodzkie i ziemskie z czasów Rzeczypospolitej Polskiej, opr. A. Prochaska, t. XX. Lauda wiszeńskie 1572-1648, Lwów 1909; t. XXI. Lauda wiszeńskie 1648-1673, Lwów 1911; t. XXII. Lauda wiszeńskie 1673-1732, Lwów 1914.

Anusiewicz J. (1995), Lingwistyka kulturowa, Wrocław.

Bajerowa I. (1993), Wpływ życia religijnego na język ogólnopolski (próba systematyzacji opisu historycznego), [w:] Język a chrześcijaństwo, red. I. Bajerowa, M. Karpluk, Z. Leszczyński, Lublin, s. 7-18.

Boryś W. (2005), Stownik etymologiczny języka polskiego, Kraków.

Cybulski M. (1992), Elementy chrześcijańskie w staropolskim obyczaju językowym, [w:] Biblia a kultura Europy, red. M. Kamińska, E. Małek, t. 1, Łódź, s. 191-207.

Dawidziak-Kładoczna M. (2018), O sposobach oddziaływania na odbiorce w uniwersałach doby średniopolskiej (na przykładzie uniwersatów sejmiku wiszeńskiego), [w:] Filologia jako porządkowanie chaosu. Studia nad językiem i tekstem. Ad honorem Professoris Marci Cybulski, red. E. Woźniak, A. Lenartowicz-Zagrodna, Łódź, s. 391-404.

Dąbrowska A., Anusiewicz J. (red.) (2000), Językowy obraz świata a kultura („Język a Kultura” 13), Wrocław.

Eliade M. (1970), Sacrum, mit, historia. Wybór esejów, przeł. A. Tatarkiewicz, Warszawa.

Eliade M. (2008), Sacrum a profanum o istocie sfery religijnej, przeł. B. Baran, Warszawa.

Kalwat W. (online), Przebieg obrad sejmików ziemskich, „Silva Rerum”, http://www.wilanow-palac.pl/przebieg_obrad_sejmikow_ziemskich.html (dostęp: 31 stycznia 2018).

Kłoskowska A. (1991), Kultura, [w:] Pojęcia i problemy wiedzy o kulturze, red. A. Kłoskowska, Wrocław, s. 17-50.

Książek-Bryłowa W. (2001), Obraz Boga w Pieśniach Wacława Potockiego, [w:] Idee chrześcijańskie w życiu Europejczyka, cz. 1, red. A. Ceglińska, Z. Staszewska, Łódź, s. 251-258.

Matuszczyk B. (2001), Idea Opatrzności Bożej w języku polskim — dawniej i dziś, [w:] Idee chrześcijańskie w życiu Europejczyka, cz. 1, red. A. Ceglińska, Z. Staszewska, Łódź, s. 277-286.

Obremski K. (1991), Obraz Boga w poezji Jana Kochanowskiego, [w:] Jan Kochanowski w czterechsetlecie śmierci, red. S. Nieznanowski, J. Święch, Lublin, s. 143-171.

Rzepka W.R., Walczak B. (1999), Bóg i szatan w polszczyźnie XVI wieku, [w:] Tysiąc lat polskiego słownictwa religijnego, red. B. Kreja, Gdańsk, s. 57-66.

Siuciak M. (2005), Od szesnastowiecznych konstytucji sejmowych do wspótczesnej Konstytucji Rzeczpospolitej Polskiej - czyli o przeobrażeniach stylu prawno-urzędowego, [w:] Wspótczesne analizy dyskursu. Kognitywna analiza dyskursu a inne metody badawcze, red. S. Gajda, M. Krauz, Rzeszów, s. 121-130.

Siuciak M. (2011), Średniowieczny dyskurs prawny - czyli o początkach stylu urzędowego, [w:] Odmiany stylowe polszczyzny dawniej i dziś, red. U. Sokólska, Białystok, s. 285-298.

Strykowska M. (1999), Obraz Boga w „Rytmach” Mikołaja Sępa Szarzyńskiego na tle prądów ideowych epoki, [w:] Tysiac lat polskiego stownictwa religijnego, red. B. Kreja, Gdańsk, s. 67-82.

Tazbir J. (1974), Polska XVII wieku. Państwo — spoleczeństwo — kultura, red. J. Tazbir, Warszawa. 
Warczok T. (2010), Symbol, czas, struktura: fundamentalizm religijny jako odpowiedź na globalizację „Górnośląskie Studia Socjologiczne. Seria Nowa” 1, s. 117-132, http://bazhum.muzhp. pl/media/files/Gornoslaskie_Studia_Socjologiczne_Seria_Nowa/Gornoslaskie_Studia_Socjologiczne_Seria_Nowa-r2010-t1/Gornoslaskie_Studia_Socjologiczne_Seria_Nowa-r2010-t1-s117-132/Gornoslaskie_Studia_Socjologiczne_Seria_Nowa-r2010-t1-s117-132.pdf (dostęp: 1 lutego 2018).

Widacka H. (online), Bójka szlachty w kościele, „Silva Rerum”, http://www.wilanow-palac.pl/bojka_szlachty_w_kosciele.html (dostęp: 31 stycznia 2018).

Wincewicz K. (2015), Językowy obraz Boga w ,Kazaniach sejmowych” Piotra Skargi, „Linguarum Silva" 4, s. 77-91.

Wojtak M. (1993), Styl urzędowy, [w:] Encyklopedia kultury polskiej XX wieku, t. 2. Wspótczesny język polski, red. J. Bartmiński, Wrocław, s. 147-162.

\section{Elements of the sacred in the legal-official style (using the example of documents of the regional councils from the 16 th to the 18 th century)}

\section{Summary}

Legal acts of the regional councils represent the legal and official style. These documents contain numerous references to the sacred, which is the result of the communication convention in force in the Middle-Polish period and Sarmatian culture, represented by the participants of this communication. The Sejmiks were most often held in the church. The dating of documents also contained religious elements. Officials applied temporal terms determined by the liturgical calendar. The sacral motifs appear in many acts of speech, both polite (in titles, wishes, thanks) and performative (in oaths). The image of God in documents is similar to God's image in literary works. God is seen above all as a creator, donor, ruler, guardian and judge. His traits are, for example, justice, kindness and mercy.

Keywords: sacrum, legal and official style, 16th-18th centuries, image of God 